http://jmscr.igmpublication.org/home/

ISSN (e)-2347-176x ISSN (p) 2455-0450

crossref DOI: https://dx.doi.org/10.18535/jmscr/v8i2.96

\title{
Evaluation of Microvascular and Macrovascular complications in patients with Type 2 Diabetes Mellitus
}

Authors

\section{Dr Kadubandi Sunil Kumar ${ }^{1}$, Dr Vineetha Kolar Venkataravanappa ${ }^{2}$, Dr Chandana Krishna ${ }^{3 *}$, Dr Lokesh M R ${ }^{4}$, Dr Sharath Kumar $\mathbf{S}^{5}$}

${ }^{1}$ Junior Resident, Department of General Medicine, ${ }^{2}$ Associate Professor, Department of General Medicine

${ }^{3}$ Assistant Professor, Department of Community Medicine

${ }^{4}$ Assistant Professor, Department of General Medicine, ${ }^{5}$ Junior Resident, Department of General Surgery

Sri Siddhartha Medical College Hospital \& Research Centre, Agalakote, Tumakuru, Karnataka-572107

*Corresponding Author

\section{Dr Chandana Krishna}

Assistant Professor, Department of Community Medicine, Sri Siddhartha Medical College Hospital \& Research Centre, Tumakuru, Karnataka, India

\begin{abstract}
Background: DM comprises a group of common metabolic disorder that shares the phenotype of Hyperglycemia.
\end{abstract}

Aim: To evaluate the Microvascular and macrovascular complications of Type 2 Diabetes Mellitus among patients attending the General Medicine OPD and IPD.

Materials and Methods: The study was a cross-sectional study done on patients with age more than 40 years with type 2 Diabetes Mellitus attending OPD and IPD for a period of 12 months. The sample size was 147 and estimated through purposive sampling method. The selected patients underwent detailed clinical and biochemical evaluations.

Results: Maximum patients with diabetes were between 60 - 69 years of age. Of the total number of patients $49 \%$ were found to be hypertensive, $39 \%$ were found to be obese, $16 \%$ of the study population were smokers and 50\% were found to have hypercholesterolaemia. The prevalence of retinopathy, neuropathy and nephropathy were 37\%, 24\% and 20\% respectively. The prevalence of coronary artery disease, peripheral vascular disease and cerebrovascular disease was found to be $29 \%$, 5\% and $10 \%$ respectively.

Conclusion: In this study $64 \%$ of patients were males and $36 \%$ were females. The mean age of the patients was 57 years. $52 \%$ of patients had duration of diabetes $<5$ years. Hypertension was found in $49 \%$ of patients.

Keywords: Diabetes Mellitus, Nephropathy, Neuropathy, Retinopathy.

\section{Introduction}

One of the most challenging problems of the 21 st century concerning health is diabetes mellitus. India is the second leading country with 65.1 million people suffering from diabetes in 2013, which is expected to go up by 109 million by $2035^{1}$. Diabetes Mellitus comprises a group of common metabolic disorder that shares the phenotype of Hyperglycemia. Several distinct types of DM exist and are caused by complex 
interaction of genetic, environmental factors and lifestyle choices.

The Two Broad Categories of DM are designated as Type 1 and Type 2 Diabetes.

- Type 1 Diabetes occurs due to auto-immune Beta cell destruction.

- Type 2 DM is a heterogeneous group of disorder characterised by variable degrees of insulin resistance, impaired insulin secretion and increased glucose production.

The chronic complication of DM affects many organ systems and is responsible for the majority of morbidity and mortality associated with the disease. The vascular complication of DM are further subdivided into Microvascular (Retinopathy, Neuropathy, Nephropathy) and Macrovascular (coronary artery disease, peripheral arterial disease and cerebrovascular disease). The microvascular complications of both Type 1 and Type 2 DM result from chronic hyperglycaemia. Since Type $2 \mathrm{DM}$ often has a long asymptomatic period of hyperglycaemia, many individuals with type 2 DM have complications at the time of diagnosis. Evidence implicating a causative role of chronic hyperglycaemia in macrovascular complications is less conclusive. Moreover, coronary heart disease events and mortality are two to four times greater in patients with Type 2 DM. Other factors like dyslipidaemia and hypertension play an important role in macrovascular complications.

\section{Aim of the Study}

1) To evaluate the microvascular and macrovascular complications of Type 2 Diabetes Mellitus.

2) To evaluate the risk factors such as hypertension, hypercholesterolaemia, obesity, and smoking.

\section{Materials and Methods \\ Study Design}

The study was a cross-sectional study done on patients with age more than 40 years with type 2 Diabetes Mellitus attending General Medicine
OPD and IPD for a period of 12 months. The sample size was estimated by purposive sampling method.

\section{Selection of Cases}

Patients with type $2 \mathrm{DM}$ aged more than 40 years attending the General Medicine OPD and IPD at Sri Siddhartha Medical College and Hospital were evaluated for

A. Risk factors- Hypertension, Obesity, Smoking and Hypercholesterolaemia.

B. Microvascular Complications- Retinopathy, Neuropathy and Nephropathy.

C. Macrovascular Complications- CAD, Cerebrovascular Disease, Peripheral Vascular Disease.

D. For evaluation of complication, they were categorised according to the duration of Diabetes.

- DM of $<5$ years.

- DM for 6 - 10 years.

- DM for 10-15 years

- DM of $>15$ years.

A detailed history was taken, particularly the duration of Type 2DM, Smoking, Complications, Family History of DM.

The following Criteria were taken/ Diagnosis of Diabetes:

\begin{tabular}{|l|}
\hline FBS $\geq 126 \mathrm{mg} / \mathrm{dL}(7.0 \mathrm{mmol} / \mathrm{L}) *$ \\
\hline $2-\mathrm{hr}$ PPBS $\geq 200 \mathrm{mg} / \mathrm{dL}(11.1 \mathrm{mmol} / \mathrm{L})$ during \\
OGTT $(75-\mathrm{g}) *$ \\
\hline HBA1C $\geq 6.5 \%(48 \mathrm{mmol} / \mathrm{mol}) *$ \\
\hline
\end{tabular}

Criteria for Risk Factors Diagnosis of Hypertension

\begin{tabular}{|l|c|c|}
\hline Stages & Systolic & Diastolic \\
\hline Pre-Hypertension & $120-139$ & $80-89$ \\
\hline Hypertension Stage 1 & $140-159$ & $90-99$ \\
\hline Hypertension Stage 2 & $>160$ & $>100$ \\
\hline
\end{tabular}

\section{Obesity}

(a) Body Mass Index $=$ Weight in $\mathrm{kgs} /$ Height in $\mathrm{m}^{2}$

- Overweight 25-30

- Obese $>30$

(b) Waist Circumference

- Male $>90 \mathrm{~cm}$

- Female $>80 \mathrm{~cm}$ 
(c) Total Cholesterol

- $<200$ Normal.

- 200 - 239 Borderline High.

- >240 High.

\section{Criteria for Microvascular Complications}

1. Diabetic Retinopathy: Ocular Fundus examination by ophthalmoscope after dilatation of pupils.

(a) Non-proliferating Diabetic Retinopathy:

- Microaneurysm, Haemorrhage, Hard Exudates

(b) Proliferative Retinopathy:

- New Vessels on Disc (NVD)

- New Vessels Elsewhere (NVE)

(c) Clinically Significant Macular Oedema (CSME):

- Thickening of retina located $500 \mu \mathrm{U} / \mathrm{m}$ from the centre of macula.

- Hard exudates with thickening of adjacent retina located $500 \mu \mathrm{U} / \mathrm{m}$ from the centre of macula.

- Zone of retinal thickening of one disk area or larger in size, located one disc diameter from the centre of macula.

\section{Diabetic Nephropathy}

(a)Macroproteinuria-Protein excretion of > 500 $\mathrm{mg} /$ day, out of which $50 \%$ is albumin. Macroalbuminuria was tested. Microalbuminuria was not tested.

(b)Serum Creatinine

- Calculation of GFR done based on Cockroft-Gault Formula.

Estimated creatinine clearance $(\mathrm{ml} / \mathrm{min})$ $=\underline{(140-\text { age }) \times \text { body weight }(\mathrm{kg})}$

$72 \times \mathrm{P}$ creatinine $(\mathrm{mg} / \mathrm{dl})$

- Multiply by 0.85 for women.

\section{Criteria for Macrovascular Complications}

\section{Cardiovascular Disease History:}

Symptoms of Angina- Chest pain.

ECG:

- LVH.

- Ischaemic Heart Disease- ST - T changes.
- Features of old MI.

Echo: (Taken where necessary as follows)

- Diastolic dysfunction in HT.

- Regional wall motion abnormalities.

- Ejection Fraction.

\section{Peripheral Vascular Disease:}

- Clinical examination of peripheral palpable arteries done.

- Doppler study was done in relevant cases.

3. Stroke: Clinical examination and detailed history for stroke was done.

\section{Results}

Total number of Patients were147. Mean Age of Patients was 57 years.

Sex distribution in this study showed male predominance (64\%) and females (36\%). Maximum patients with diabetes are between 60 69 years as shown in Table 1.52\% of Patients have duration of Diabetes of $<5$ years as shown in Table 2. Positive Family History of DM in 32\% of Patients as shown in Table 3. Total Number of Patients with Hypertension in Diabetes is $49 \%$ as shown in Table 4. Total Number of Patients with obesity in Diabetes is 39\% as shown in Table 5. Total Number of Patients with Hypercholesterolaemia in Diabetes is $39 \%$ as shown in Table 6. In our study most common risk factor with DM is hypercholesterolaemia followed by hypertension and overall risk factors are more in males when compared to females

as shown in Table 7. Retinopathy is the most common microvascular complication followed by neuropathy as shown in Table 8.Non-proliferative Retinopathy is the most common complication in Retinopathy as shown in Table 9. The most common macrovascular complication is CAD (29\%) as shown in the Table $\mathbf{1 0 .}$ 
Table 1 Age and Sex Distribution

\begin{tabular}{|l|l|l|l|}
\hline AGE (YRS) & MALE & FEMALE & N=147 \\
\hline $40-49$ & 25 & 14 & 39 \\
\hline $50-59$ & 25 & 17 & 42 \\
\hline $60-69$ & 29 & 14 & 43 \\
\hline $70-79$ & 12 & 6 & 18 \\
\hline $80 \&$ ABOVE & 3 & 2 & 5 \\
\hline & 94 & 53 & 147 \\
\hline
\end{tabular}

Table 2. Duration of DM

\begin{tabular}{|l|c|}
\hline \multicolumn{1}{|c|}{ DURATION } & FREQUENCY(\%) \\
\hline$\leq 5$ YRS & $77(52.4)$ \\
\hline 6 -10YRS & $35(23.8)$ \\
\hline $11-15$ YRS & $21(14.3)$ \\
\hline$>15$ YRS & $14(9.5)$ \\
\hline TOTAL & 147 \\
\hline
\end{tabular}

Table 3. Positive Family History with DM

\begin{tabular}{|l|l|}
\hline FAMILY HISTORY OF DM & TOTAL N=147 \\
\hline POSITIVE & $32 \%$ \\
\hline NEGATIVE & $68 \%$ \\
\hline
\end{tabular}

Table 4. Category of Hypertension and DM

\begin{tabular}{|l|l|l|l|l|l|}
\hline CATEGORY & $\begin{array}{l}<5 \text { YEARS } \\
(\mathrm{N}=77)\end{array}$ & $\begin{array}{l}6-10 \\
\text { YEARS } \\
(\mathrm{N}=35)\end{array}$ & $\begin{array}{l}11-15 \\
\text { YEARS } \\
(\mathrm{N}=21)\end{array}$ & $\begin{array}{l}>15 \text { YEARS } \\
(\mathrm{N}=14)\end{array}$ & $\begin{array}{l}\text { TOTAL } \\
(\mathrm{N}=147)\end{array}$ \\
\hline $\begin{array}{l}\text { PRE-HT } \\
120-139 \\
80-89\end{array}$ & 5 & 12 & 3 & 2 & 22 \\
\hline $\begin{array}{l}\text { STAGE } 1 \\
140-159 \\
90-99\end{array}$ & 11 & 14 & 10 & 4 & 39 \\
\hline $\begin{array}{l}\text { STAGE } 2 \\
160 / 100 \\
\text { AND } \\
\text { ABOVE }\end{array}$ & 6 & 2 & 1 & 2 & 11 \\
\hline TOTAL & $22(29 \%)$ & $28(80 \%)$ & $14(67 \%)$ & $8(57 \%)$ & $72(49 \%)$ \\
\hline
\end{tabular}


Table 5. Obesity and Duration of DM

\begin{tabular}{|l|l|l|l|l|l|}
\hline OBSEITY & $\begin{array}{l}\text { <5YEARS } \\
(\mathrm{N}=77)\end{array}$ & $\begin{array}{l}6-10 \\
\text { YEARS } \\
(\mathrm{N}=35)\end{array}$ & $\begin{array}{l}11-15 \\
\text { YEARS } \\
(\mathrm{N}=21)\end{array}$ & $\begin{array}{l}>15 \text { YEARS } \\
(\mathrm{N}=14)\end{array}$ & $\begin{array}{l}\text { TOTAL } \\
(\mathrm{N}=147)\end{array}$ \\
\hline $\begin{array}{l}\text { OVERWEIGHT } \\
25-30\end{array}$ & 14 & 18 & 9 & 5 & $46(31 \%)$ \\
\hline OBESE $>30$ & 3 & 3 & 3 & 2 & $11(8 \%)$ \\
\hline TOTAL & $17(22 \%)$ & $21(60 \%)$ & $12(57 \%)$ & $7(50 \%)$ & $57(39 \%)$ \\
\hline
\end{tabular}

Table 6. DM and Hypercholesterolaemia

\begin{tabular}{|l|l|l|l|l|}
\hline $\begin{array}{l}\text { TOTAL } \\
\text { CHOLESTEROL } \\
\text { MG/DL }\end{array}$ & $\begin{array}{l}\text { <5YEARS } \\
(\mathrm{N}=77)\end{array}$ & $\begin{array}{l}6-10 \text { YEARS } \\
(\mathrm{N}=35)\end{array}$ & $\begin{array}{l}11-15 \text { YEARS } \\
(\mathrm{N}=21)\end{array}$ & $\begin{array}{l}>15 \text { YEARS } \\
(\mathrm{N}=14)\end{array}$ \\
\hline $200-239$ & 8 & 14 & 8 & 5 \\
\hline $\begin{array}{l}240 \text { AND } \\
\text { ABOVE }\end{array}$ & 13 & 14 & 9 & 3 \\
\hline TOTAL & $21(27 \%)$ & $28(80 \%)$ & $17(81 \%)$ & $8(57 \%)$ \\
\hline
\end{tabular}

Table 7. Risk Factor and DM

\begin{tabular}{|l|l|l|l|}
\hline RISK FACTOR & MALE & FEMALE & TOTAL \\
\hline HYPERTENSION & 42 & 30 & $72(49 \%)$ \\
\hline OBESITY & 30 & 27 & $57(39 \%)$ \\
\hline SMOKING & 24 & 0 & $24(16 \%)$ \\
\hline HYPERCHOLESTEROLAEMIA & 38 & 36 & $74(50 \%)$ \\
\hline
\end{tabular}

Table 8. Microvascular Complication and Duration on DM

\begin{tabular}{|l|l|l|l|l|l|}
\hline $\begin{array}{l}\text { MICROVASCULAR } \\
\text { COMPLICATION }\end{array}$ & $\begin{array}{l}\text { <YEARS } \\
(\mathrm{N}=77)\end{array}$ & $\begin{array}{l}6-10 \\
\text { YEARS } \\
(\mathrm{N}=35)\end{array}$ & $\begin{array}{l}11-15 \\
\text { YEARS } \\
(\mathrm{N}=21)\end{array}$ & $\begin{array}{l}>15 \\
\text { YEARS } \\
(\mathrm{N}=14)\end{array}$ & $\begin{array}{l}\text { TOTAL } \\
(\mathrm{N}=147)\end{array}$ \\
\hline RETINOPATHY & $8(10 \%)$ & $13(37 \%)$ & $19(90 \%)$ & $14(100 \%)$ & $54(37 \%)$ \\
\hline NEUROPATHY & $6(8 \%)$ & $9(26 \%)$ & $12(57 \%)$ & $9(64 \%)$ & $36(24 \%)$ \\
\hline NEPHROPATHY & $6(8 \%)$ & $4(11 \%)$ & $8(38 \%)$ & $11(76 \%)$ & $29(20 \%)$ \\
\hline
\end{tabular}

Table 9. Types of Diabetic Retinopathy

\begin{tabular}{|l|l|}
\hline TYPES & TOTAL $(\mathrm{N}=54)$ \\
\hline NON PROLIFERATIVE RETINOPATHY & $39(72 \%)$ \\
\hline PROLIFERATIVE RETINOPATHY & $12(22 \%)$ \\
\hline MACULOPATHY & $3(6 \%)$ \\
\hline
\end{tabular}


Table 10. Macrovascular Complications and DM

\begin{tabular}{|l|l|}
\hline COMPLICATION & TOTAL N=147 \\
\hline CAD & $42(29 \%)$ \\
\hline PVD & $8(5 \%)$ \\
\hline CVA & $14(10 \%)$ \\
\hline
\end{tabular}

\section{Discussion}

The total no. of patients analysed were 147 , out of which $64 \%$ were male and $36 \%$ were female patients. The mean age of patients found in the study was $57 \mathrm{yrs}$. These findings correlate with studies done by Raheja et $\mathrm{al}^{2}$, which showed the mean age of 53.3 years. The prevalence of diabetes increases with age. In this study maximum case in elderly being 61-69 years' age group. This finding correlate with studies done by Ahuja $\mathrm{MMS}^{3}$. Epidemiological studies of DM in India showed prevalence of diabetes in elderly patients (age > $60 \mathrm{yrs}$.) in urban population as $23.4 \%$ and maximum prevalence was in age group of 61 - 69 years. Out of 100 patients, 32\% cases had positive family history of diabetes. Many Indian studies show strong association of positive family history in DM type 2. These findings correlate with study of Shah et $\mathrm{al}^{4}$, which showed positive family history of $24.9 \%$ and Ramachandran et $\mathrm{al}^{5}$ which showed strong correlation of positive family history with DM type 2. Hypertension: The prevalence of hypertension in diabetes in the present study is 49\%. CDC's National Diabetes Surveillance System 2005 USA $^{6}$ shows $62.5 \%$ of patients have hypertension in diabetes. Among the stages of hypertension according to JNC VII report, maximum patients $54 \%$ were in Stage 1 . Various Indian studies show prevalence of hypertension in DM to be around 50\% - 80\%. Obesity: This study shows that $39 \%$ patients were overweight and obese according to BMI. Many of Indian studies showed strong correlation between obesity and DM type 2. Smoking: $16 \%$ of the patients in the present study were smokers and all of them were males. A study by SV Madhu et $\mathrm{al}^{7}$ showed smokers to be $15 \%$ and an International study by
CDC- National Diabetes Surveillance System, 2005, USA $^{6}$ shows smokers at $17.7 \%$ among diabetic patients. Hypercholesterolaemia: Out of 147 patients, $50 \%$ patients had hypercholesterolaemia. This study correlates with a study done by CDC- National Diabetes Surveillance System, 2005, USA ${ }^{6}$, which showed the hypercholesterolaemia at $60 \%$ and a study done by $\mathrm{S}$ Shafiq et $\mathrm{al}^{8}$. The most common risk factor in diabetes is hypercholesterolaemia, which is $50 \%$. Next common risk factor is hypertension. All these risk factors play a significant role in the pathogenesis of Macrovascular complications. Microvascular Complications: Diabetic Retinopathy $37 \%$ is the most common microvascular complication. Out of the patients with Retinopathy, $72 \%$ had non-proliferative Retinopathy. The prevalence of Retinopathy increases according to the duration of diabetes. This study correlates with the study done by $G$ Premalatha and V Mohan et $\mathrm{al}^{9}$ in Urban South Indian Population, which showed that Retinopathy was $34.1 \%$ and $\mathrm{M}$ Ranka et $\mathrm{al}^{10}$ found it to be $28.9 \%$ in a North Indian study. CKD in Diabetes was seen in $20 \%$ of patients in the study. Out of the patients with $\mathrm{CKD}$, maximum patients i.e. $48 \%$ were in Stage $1.18 \%$ of them had Proteinuria. Microalbuminuria was not done in this study. The finding however correlates with the study done by Ramachandra et $\mathrm{al}^{5}$ which showed prevalence of Proteinuria at $19.7 \%$.

Diabetic Neuropathy was prevalent in $24 \%$ of patients. This finding however correlates with the study done by G Premalatha and V Mohan et $\mathrm{al}^{9}$ which had $19.1 \%$ patients with Neuropathy. Macrovascular Complications: Coronary Artery Disease- $29 \%$ is the most common Macrovascular complication in the study. $14 \%$ of patients with 
CAD had duration of DM of $<5$ years. Peripheral Vascular Disease was present in $5 \%$ of patients in the study. This correlates with the study by $G$ Premalatha and $\mathrm{V}$ Mohan et $\mathrm{al}^{9}$ which showed $4 \%$. Cerebrovascular disease was seen in $10 \%$ of patients in the study. This correlates with the International Study CDC- National Diabetes Surveillance System, 2005, USA ${ }^{6}$ which showed $9 \%$ prevalence of stroke in type $2 \mathrm{DM}$.

\section{Conclusion}

- In this study $64 \%$ of patients were males and $36 \%$ were females, all of them being above 40 years of age.

- The mean age of the patients was 57 years.

- Maximum number of partcipants were seen in age group of 61 - 69 years.

- $52 \%$ of patients had duration of diabetes < 5 years.

- Hypertension was found in $49 \%$ of patients.

- Obesity was found in $39 \%$ of patients.

- $26 \%$ of the males were smokers.

- Hypercholesterolaemia was found in $50 \%$ of patients.

- The highest risk factor was Hypercholesterolaemia followed by Hypertension.

- Retinopathy was found in $37 \%$ of patients.

- Neuropathy was found in $24 \%$ of the patients.

- Nephropathy was found in $20 \%$ of the DM patients.

- Coronary artery disease was found in $29 \%$ of patients.

- Peripheral Vascular Disease was found in $5 \%$ of patients.

- Cerebrovascular disease was seen in $10 \%$ of patients.

Acknowledgement: NIL

Financial Support: Nil

\section{References}

1. International Diabetes Federation. IDF Diabetes Atlas, $6^{\text {th }}$ edn. Brussels, Belgium: International Diabetes Federation; 2013. http://www.idf.org/ diabetes atlas.

2. Raheja BS, Kapur A, Bhoraskar A, et al. Diab Care Asia--India study: diabetes care in India--current status. The Journal of the Association of Physicians of India 2001;49:717-22.

3. Ahuja MMS. Diabetes mellitus in India in the context of social change. Bombay, India: Health Care Communications 1996.

4. Shah SK, Saikia M, Burman NN, et al. High prevalence of type 2 diabetes in urban population in north eastern India. Int J Diabetes Dev Countries 1999;19:144-7.

5. Ramachandran A, Snehalatha C, Satyavani $\mathrm{K}$, et al. Prevalence of vascular complications and their risk factors in type 2 diabetes. The Journal of the Association of Physicians of India 1999;47(12): 11526.

6. National estimates on diabetes - CDC, HIS, US Renal Data System of the NIH: census bureau. 2005.

7. Madhu SV, Singh NR. Prevalence of cardiovascular risk factor at presentation with Type 2 DM. JAPI 2002.

8. Shafiq J, Ahmed. Profile of dyslipidaemia in type 2 diabetic subject - a hospital based study. JAPI 2001.

9. Premalatha G, Rema M. Diabetes and related complications in urban South Indians: type 2 Diabetes -the Indian Scenario 2025? -1st edn. Publ.Dr M. Jayaram 2002:185-9.

10. Ranka M, Katyal V. Prevalence of micro and macro vascular complications and their risk factors on DM type 2 - a Study from North India - Int $\mathrm{J}$ Diab Dev Countries 2004;24:11-6. 